\title{
The Pact of the Catacombs: An Early Harbinger of Pope Francis' Vision of the Church
}

\begin{abstract}
Hector Scerri
University of Malta, Msida, Malta

Fifty-four years ago, the Pact of the Catacombs was signed by a small group of churchmen, determined to make a difference. It was the time of the Second Vatican Council. It was the closing phase of that momentous experience in the Church's life—a transforming event about which many still talk about, half a century later. A handful of bishops-40 out of an impressive 2,000-plus contingent meeting in St Peter's Basilica-decided to assemble at the dead of night in the Catacombs of Domitilla, outside Rome. During that eventful night of 16 November 1965, they dreamt of a poor servant church. In that holy place, beneath the earth's surface, where many generations of early Christians met to pray and to bury their loved ones, those 40 modern-day bishops met in heartfelt prayer to celebrate the Eucharist. They also signed the Pact of the Catacombs as they committed themselves to the ideals of Vatican II. The group of like-minded courageous shepherds was led by Archbishop Helder Camara of Recife, Brazil, the revered champion of the downtrodden poor and marginalized. Those gathered made a common pledge to live according to the daily manner of ordinary people, with regard to housing, food, means of transport, and such routine needs. In the Pact, they renounced the appearance and trappings of wealth, especially the use of gaudy vestments, resembling those of earthly monarchs, and symbols of precious metals, insisting that such signs should rather be according to the spirit of the Gospel. They promised to divest themselves of earthly riches and properties, and if they had to possess anything they placed it in the name of the diocese or some charitable foundation. In the humble consoling light of flickering candles, the group renounced all those aspects which appeared to be associated with privilege, prominence, and the wealthy echelons of society. In line with this, they expressed their desire not to be addressed verbally or in writing with titles expressing power, but rather with the more scriptural and homely title of "Father". Their evangelical intention was focused on avoiding any sort of vanity. The signatories that night at the Domitilla Catacombs affirmed that "we will give whatever is needed in terms of our time, our reflection, our heart, our means, etc., to the apostolic and pastoral service of workers and labour groups and to those who are economically weak and disadvantaged, without allowing that to detract from the welfare of other persons or groups of the diocese. We will support lay people, religious, deacons and priests whom the Lord calls to evangelize the poor and the workers, by sharing their lives and their labours". This paper shows how the Pact of the Catacombs was to be an early harbinger of Pope Francis' vision of the church.
\end{abstract}

Keywords: Pact of the Catacombs, Domitilla Catacombs, simplicity, poverty, church, Pope Francis, Helder Camara

Msgr Prof. Hector Scerri, S.Th.D., Deputy Dean and Associate Professor, Faculty of Theology, Department of Fundamental \& Dogmatic Theology, University of Malta, Msida, Malta. 


\section{Introduction: A Flashback to November 1965}

The 16th day of November marks an important anniversary, unfortunately unsung and un-commemorated for nearly half a century. Fifty-four years ago, on Tuesday 16 November 1965, the Pact of the Catacombs was signed by twoscore bishops, determined to embrace a radical commitment which would send ripples to the ends of the Catholic Church. It was the bustling period of the Second Vatican Council.

A handful of bishops-40 out of an impressive 2,000-plus assembly in St Peter's Basilica-decided to convene in the Catacombs of Domitilla, outside Rome (Scerri, 2015). Different sources provide us with different tallies of signatories: 37, 39, 40, and 57 (Pikaza \& Antunes da Silva, 2015; Pani, 2015; Arntz, 2015a). Later, 500 other bishops joined in signing the Pact (Kasper, 2015; Pani, 2015) which was presented to Pope Paul VI by Cardinal Lercaro of Bologna.

During that eventful 16 November 1965, they dreamt of a poor servant church. In that holy place, beneath the earth's surface, where many generations of early Christians met to pray and to bury their loved ones, those modern-day bishops met in heartfelt prayer to celebrate the Eucharist, presided by Bishop Charles Marie Himmer of Tournai (Belgium). They then signed the Pact of the Catacombs as they committed themselves to the ideals of Vatican II. National Catholic Reporter journalist David Gibson writes:

With its Dan Brown setting and murky evidence, the pact seemed fated to become another Vatican mystery-an urban legend to those who had heard rumours about it, or at best a curious footnote to church history rather than a new chapter. (Gibson, 2015)

\section{The Motivation Underlying the Pact of the Catacombs and its Contents}

The group of like-minded courageous shepherds found their inspiration from various sources (Arntz, 2015b), besides the Word of God in the Scriptures: (i) the so-called "Group of Nazareth", Paul Gauthier and the group "Church of the poor"; (ii) the spirituality of Charles de Foucauld; (iii) Yves Congar's work Pour une Église servante et pauvre (1963) (Congar, 2005) ${ }^{1}$; and (iv) the positively contagious personality of Bishop Hélder Camara (1909-1999) of Recife, Brazil, then already revered as the champion of the downtrodden poor and marginalized (Camara, 2008) ${ }^{2}$. Those gathered at the Domitilla Catacombs made a common pledge to live according to the daily manner of ordinary people, with regard to housing, food, means of transport and such routine needs.

In the Pact, they renounced the appearance and trappings of wealth, especially the use of gaudy vestments, resembling those of earthly monarchs, and symbols made of precious metals, insisting that such signs should rather be according to the spirit of the Gospel. They promised to divest themselves of earthly riches and properties, and if they had to possess anything, they placed it in the name of the diocese or some charitable foundation.

In the humble consoling light of flickering candles, the group renounced all those aspects which appeared

\footnotetext{
${ }^{1}$ In the entry for 1 October 1964 of his Council Diary, Yves Congar mentions Mons. Himmer and the Church of the Poor. He mentions the suggestion for the removal of honorific titles and the adoption of simplicity: "Mons. Himmer, a proposito della Chiesa dei Poveri, mi dice: manderemo una lettera al Papa. Suggeriamo l'abbandono dei titoli onorifici e anche che il vescovo possa vestirsi come tutti i preti; quanto ai paramenti liturgici, mantenere la semplicità".

${ }^{2}$ In one of his letters, written during the Council, Camara-who at the last moment could not be present at the Domitilla Catacombs due to a meeting regarding a late draft of Gaudium et Spes-refers to the Pact: "Ci sono già state la concelebrazione nelle Catacombe (in torno a Mons. Himmer) e la concelebrazione nella chiesa di Cardijn. Avrò modo di commentare i testi delle due Promesse".
} 
to be associated with privilege, prominence, and the wealthy echelons of society. In line with this, they expressed their desire not to be addressed verbally or in writing with titles expressing power (such as Eminence, Excellency, and Lordship), but rather with the more scriptural and homely title of Father. Their evangelical intention was focused on avoiding any sort of vanity.

The signatories that day at the Domitilla Catacombs affirmed that

we will give whatever is needed in terms of our time, our reflection, our heart, our means, etc., to the apostolic and pastoral service of workers and labour groups and to those who are economically weak and disadvantaged, without allowing that to detract from the welfare of other persons or groups of the diocese. We will support lay people, religious, deacons and priests whom the Lord calls to evangelize the poor and the workers, by sharing their lives and their labours.

They committed themselves to promote all initiatives based on justice and charity, insofar that all persons, whoever they are, would be served. The Pact also bound those who signed it to work hand-in-hand with those in civil authority by encouraging them, to

establish and enforce laws, social structures and institutions that are necessary for justice, equality and the integral, harmonious development of the whole person and of all persons, and thus for the advent of a new social order, worthy of the children of God.

Strongly convinced of the real meaning of pastoral charity, the members of the group committed themselves to share their life

with our brothers and sisters in Christ...so that our ministry constitutes a true service.... We will seek collaborators in ministry so that we can be animators according to the Spirit rather than dominators according to the world; we will try to make ourselves as humanly present and welcoming as possible; and we will show ourselves to be open to all, no matter what their beliefs are.

The author of this article is sure that had Jorge Mario Bergoglio been present at Domitilla's Catacombs-he was far away, in Argentina, and still in his formation years as a Jesuit-he would have agreed with the letter and the spirit of the Pact. In the way he speaks and acts, Pope Francis, like others, puts into practice the substance of the Pact of the Catacombs.

\section{Pope Francis: “A Church Which is Poor and for the Poor”}

Indeed, David Gibson (2015) stated that

perhaps nothing has revived and legitimated the Pact of the Catacombs as much as the surprise election, in March 2013, of Argentine Cardinal Jorge Mario Bergoglio-Pope Francis. While never citing the Catacombs Pact specifically, Francis has evoked its language and principles. (Gibson, 2015)

We will now seek to demonstrate the truth of the earlier assertion, and the title of this paper. From the earliest days of his ministry as Bishop of Rome, Francis underlined that the Church is called to be a Church of the poor. In his widely-publicized encounter with journalists and the media, three days after his election, he affirmed in very clear terms: "How I would like a Church which is poor and for the poor!" (Francis, 2013)

A good number of the texts chosen from the Papal Magisterium since March 2013, for the purpose of this paper, reveal a surprising convergence with the content of the Pact of the Catacombs. In what has often been called his pastoral programme, Pope Francis, in Evangelii Gaudium, sought to address a wide spectrum of pressing, albeit, general ecclesiological issues. More or less reiterating in this text his words to the media, the words just referred to, he states: 
For the Church, the option for the poor is primarily a theological category rather than a cultural, sociological, political or philosophical one. God shows the poor "his first mercy". This divine preference has consequences for the faith life of all Christians, since we are called to have "this mind... which was in Jesus Christ" (Phil 2:5). Inspired by this, the Church has made an option for the poor which is understood as a "special form of primacy in the exercise of Christian charity, to which the whole tradition of the Church bears witness". [...] This is why I want a Church which is poor and for the poor. They have much to teach us. Not only do they share in the sensus fidei, but in their difficulties they know the suffering Christ. We need to let ourselves be evangelized by them. [...] We are called to find Christ in them, to lend our voice to their causes, but also to be their friends, to listen to them, to speak for them and to embrace the mysterious wisdom which God wishes to share with us through them ${ }^{3}$.

\section{An Extrovert Church}

There are several other instances in Evangelii Gaudium where we can see a clearly audible echo of the Pact of the Catacombs. This is evident in the "refrain" Francis sings on other occasions, namely, his sincere desire of being a Church which goes forth, a Church whose doors are wide open, with the aim of reaching out to all, especially those on the fringes of society ${ }^{4}$, a Church which is not a tollhouse (an expression he has also used in the Exhortation Amoris Laetitia), and so a place where everyone can feel at home ${ }^{5}$, a Church which is

bruised, hurting and dirty because it has been out on the streets, rather than a Church which is unhealthy from being confined and from clinging to its own security. I do not want a Church concerned with being at the centre and which then ends by being caught up in a web of obsessions and procedures ${ }^{6}$.

Born in the context of the Second Vatican Council, the Pact of the Catacombs, is-as we have seen earlier-mainly addressed to bishops in a call to commit themselves to a radical shift from a princely lifestyle to gospel simplicity. In Evangelii Gaudium, Pope Francis-in the spirit of the Pact, as well as from what characterises his own simple, hands-on, shepherd-like lifestyle-affirms the bishop's missionary duty as the facilitator of communion. He colourfully elaborates upon the true shepherd (or co-shepherd) of Christ's flock, very different from a princely demeanour:

To do so, he will sometimes go before his people, pointing the way and keeping their hope vibrant. At other times, he will simply be in their midst with his unassuming and merciful presence. At yet other times, he will have to walk after them, helping those who lag behind and-above all—allowing the flock to strike out on new paths ${ }^{7}$.

\section{Back to Basics}

The annual address to the members of the Roman Curia, a few days before Christmas, has often offered Francis with the opportunity to remind all the members of the Church (and so, not only his collaborators in the central administration of the Church) about the call to simplicity, and all that is entailed in embracing an attitude which is none other than a "back-to-basics" approach. In the speech given in December 2014, he dwelt upon a number of "curial" diseases. Among these, one is invited to pause on just three of them which help us recall the main thrust the Pact of the Catacombs sought to counter: (a) mental and spiritual petrification; (b) rivalry and vainglory; and (c) worldly profit and self-exhibition. One can underline some of Bergoglio's more striking affirmations:

\footnotetext{
${ }^{3}$ Francis, Apostolic Exhortation Evangelii Gaudium (24 November 2013), par. 198.

4 See ibid., par. 46; 24.

5 See ibid., par. 47; Francis, Apostolic Exhortation Amoris Laetitia (19 March 2016), par. 310.

${ }^{6}$ Francis, Evangelii Gaudium, par. 49.

${ }^{7}$ Ibid., par. 31.
} 
Then too there is the disease of mental and spiritual "petrification". It is found in those who have a heart of stone, the "stiff-necked" (Acts 7:51-60), in those who in the course of time lose their interior serenity, alertness and daring, and hide under a pile of papers, turning into paper pushers and not men of God (cf. Heb 3:12). It is dangerous to lose the human sensitivity that enables us to weep with those who weep and to rejoice with those who rejoice! This is the disease of those who lose "the sentiments of Jesus" (cf. Phil 2:5-11)...

The disease of rivalry and vainglory. When appearances, the colour of our clothes and our titles of honour become the primary object in life, we forget the words of Saint Paul: "Do nothing from selfishness or conceit but in humility count others better than yourselves. Let each of you look not only to his own interests, but also to the interests of others" (Phil 2:3-4). This is a disease which leads us to be men and women of deceit...

The disease of worldly profit, of forms of self-exhibition. When an apostle turns his service into power, and his power into a commodity in order to gain worldly profit or even greater power. This is the disease of persons who insatiably try to accumulate power.... (Francis, 2014)

After talking about Curial diseases, a year later, in December 2015, Francis dwelt upon what he called Curial "antibiotics" which he addressed to all members of the Church, in particular to those in authority. Among these "antibiotics", he mentioned humanity, fidelity, gentleness, openness, accountability, and sobriety. With regard to the latter, he stated:

Sobriety-the last virtue on this list, but not because it is least important-is the ability to renounce what is superfluous and to resist the dominant consumerist mentality. Sobriety is prudence, simplicity, straightforwardness, balance and temperance. Sobriety is seeing the world through God's eyes and from the side of the poor. Sobriety is a style of life which points to the primacy of others as a hierarchical principle and is shown in a life of concern and service towards others. The sober person is consistent and straightforward in all things, because he or she can reduce, recover, recycle, repair, and live a life of moderation. (Francis, 2015a)

In December 2016, Pope Francis focused on the theme of the on-going reform of the Church, ecclesia semper reformanda. Again, we can read several strands of that speech in the light of the Pact of the Catacombs. I single out a few lines from that speech:

Here I spontaneously think of the ancient adage that describes the process of the Spiritual Exercises in the Ignatian method: deformata reformare, reformata conformare, conformata confirmare et confirmata transformare.

There can be no doubt that, for the Curia, the word reform is to be understood in two ways. First of all, it should make the Curia con-form "to the Good News which must be proclaimed joyously and courageously to all, especially to the poor, the least and the outcast". To make it con-form to the signs of our time and to all its human achievements, so as "better to meet the needs of the men and women whom we are called to serve"... Since the Curia is not an immobile bureaucratic apparatus, reform is first and foremost a sign of life, of a Church that advances on her pilgrim way, of a Church that is living and for this reason semper reformanda, in need of reform because she is alive. (Francis, 2016).

\section{Servants, not Princes}

During his homily, in June 2017, during the Public Consistory for the Creation of five new cardinals, Pope Francis underlined that they are not to behave as princes, but rather, to have service as their defining hallmark. He affirmed:

Jesus "is walking ahead of you", and he asks you to follow him resolutely on his way. He calls you to look at reality, not to let yourselves be distracted by other interests or prospects. He has not called you to become "princes" of the Church, to "sit at his right or at his left". He calls you to serve like him and with him. To serve the Father and your brothers and sisters. [...] Follow him, and walk ahead of the holy people of God, with your gaze fixed on the Lord's cross and resurrection. (Francis, 2017a) 
During the previous occasions when he imposed the scarlet biretta on those chosen to be cardinals, Pope Francis emphasised simplicity, service and humility. In February 2015, he highlighted the subtle distinction between the words "honour" (associated with the cardinalate) and "honorific". In very practical terms, he harped upon the temptations of jealousy, pride, self-centredness and self-interest:

We humans-all of us, at every stage of our lives—are inclined to jealousy and pride, since our nature is wounded by sin. Nor are Church dignitaries immune from this temptation... The self-centred person inevitably seeks his own interests; he thinks this is normal, even necessary. Those "interests" can even be cloaked in noble appearances, but underlying them all is always "self-interest". Charity, however, makes us draw back from the centre in order to set ourselves in the real centre, which is Christ alone. Then, and only then, can we be persons who are respectful and attentive to the good of others. (Francis, 2015b)

On 14 September 2017, while addressing bishops ordained in the previous twelve months, Pope Francis dwelt chiefly on the importance of discernment. During his speech and reading between the lines, one can again identify persistent echoes of the Pact of the Catacombs:

The mission awaiting you does not consist in bringing your own ideas and projects, nor in solutions thought out in an abstract way by who considers the Church to be his own personal orchard, but humbly, without seeking the limelight or narcissism, to offer your own concrete witness to union with God, serving the Gospel which is to be cultivated and helped to grow in that particular situation. Discernment, therefore, means humility and obedience, humility regarding your personal projects.... (Francis, 2017b) ${ }^{8}$

\section{Trajectories for an On-Going Conversion of the Church}

The striking convergence between the text of the Pact of the Catacombs (1965) and the thought of Pope Francis is markedly conspicuous in the passages which have been highlighted. The convergence can be summarized in the following five interrelated aspects:

(1) The emphasis on the preferential option of the poor which entails a closeness to them, serving and listening to them, and an openness to being evangelized by them;

(2) An extrovert, courageous church which is prophetic;

(3) An authentic understanding of authority in the church as service, and thus, being at the beck and call of the members of Christ's flock;

(4) Embracing Gospel simplicity against excessive bureaucracy, rivalry, vainglory, worldly profit, self-exhibition, self-centredness, narcissism within the church;

(5) The commitment to fidelity, gentleness, sobriety, selfless availability and generous service.

In a spirit of on-going conversion, the Church progressively continues to discover her call to be ecclesia semper reformanda. Pope Francis puts this into practice through his continuous reaching out to the poor which is inextricably bound to his clear pastoral options and the way he seeks to implement them. The very spirit of the Pact of the Catacombs has emerged strongly in the pastoral style and impetus of Pope Francis. St Cyprian of Carthage would certainly have approved by repeating a saying often attributed to him, Extra pauperes, nulla salus! (Without serving the poor... without embracing poverty, there is no salvation!)

\footnotetext{
${ }^{8}$ Author's translation of: "La missione che vi attende non è portare idee e progetti propri, né soluzioni astrattamente ideate da chi considera la Chiesa un orto di casa sua, ma umilmente, senza protagonismi o narcisismi, offrire la vostra concreta testimonianza di unione con Dio, servendo il Vangelo che va coltivato e aiutato a crescere in quella situazione specifica. Discernere significa pertanto umiltà e obbedienza. Umiltà rispetto ai propri progetti...”.
} 


\section{Conclusion}

The Pact of the Catacombs, as we have seen, was a remarkable experience in the life of the Catholic Church. To the eyes of many, the event which took place on 16 November 1965, may seem like a humble drop in the vast ocean of happenings surrounding the Second Vatican Council. Yet, the central tenets of the Pact are now clearly echoed in the pastoral vision which Pope Francis seeks to transmit to the whole Church and to contemporary society. This is indeed encouraging. This is a wake-up call to all Christians to embrace the simplicity and the radicality of the Gospel message of Jesus Christ.

\section{References}

Arntz, N. (2015a). Der Katakombenpakt. Für eine dienende und arme Kirche (The Pact of the Catacombs. For a servant and a poor Church). Kevelaer Topos.

Arntz, N. (2015b). Por una Iglesia servidora y pobre. El Pacto de las Catacumbas come legado subversive del Vaticano II (For a servant and a poor Church. The Pact of the Catacombs as an underlying legacy of Vatican II). In X. Pikaza \& J. Antunes da Silva (Eds.), El Pacto de las Catacumbas (The Pact of the Catacombs) (pp. 113-114). Estella: Editorial Verbo Divino.

Camara, H. (2008). Roma, Due del mattino. Lettere dal Concilio Vaticano II (Rome, at two in the morning. Letters from Vatican Council II). San Paolo: Cinisello Balsamo.

Congar, Y. (2005). Diario del Concilio (Diary of the Council). San Paolo: Cinisello Balsamo.

Francis. (2013). Audience to representatives of the communications media. Retrieved 17 August, 2017, from http://w2.vatican.va/content/francesco/en/speeches/2013/march/documents/papa-francesco_20130316_rappresentanti-media. html

Francis. (2014). Address during presentation of Christmas greetings to the Roman Curia. Retrieved 19 August, 2017, from http://w2.vatican.va/content/francesco/en/speeches/2014/december/documents/papa-francesco_20141222_curia-romana.html

Francis. (2015a). Address during presentation of Christmas greetings to the Roman Curia. Clementine Hall. Retrieved 19 August, 2017 ,

http://w2.vatican.va/content/francesco/en/speeches/2015/december/documents/papa-francesco_20151221_curia-romana.html

Francis. (2015b). Homily, public consistory for the creation of twenty new cardinals. Retrieved 18 August, 2017, from http://w2.vatican.va/content/francesco/en/homilies/2015/documents/papa-francesco_20150214_omelia-concistoro-nuovi-cardinali.h tml

Francis. (2016). Address during presentation of Christmas greetings to the Roman Curia. Retrieved 19 August, 2017, from http://w2.vatican.va/content/francesco/en/speeches/2016/december/documents/papa-francesco_20161222_curia-romana.html

Francis. (2017a). Homily, public consistory for the creation of five new cardinals. Retrieved 18 August, 2017, from http://w2.vatican.va/content/francesco/en/homilies/2017/documents/papa-francesco_20170628_concistoro.html

Francis. (2017b). Address to newly-ordained Bishops. Retrieved from http://w2.vatican.va/content/francesco/it/speeches/2017/september/documents/papa-francesco_20170914_nuovi-vescovi.html

Gibson, D. (2015). Secret “Catacombs Pact” emerges after 50 years, and Francis gives it new life. Retrieved 1 October, 2017, from https://www.ncronline.org/news/vatican/secret-catacombs-pact-emerges-after-50-years-and-francis-gives-it-new-life

Kasper, W. (2015). Pope Francis' revolution of tenderness and love. New York and Mahwah, NY: Paulist Press.

Pani, G. (2015). Il patto delle catacombe (The Pact of the Catacombs). La Civiltà Cattolica (The Catholic Civilization), 166(4), 547-549.

Pikaza, X., \& Antunes da Silva, J. (2015). El Pacto de las Catacumbas. La mission de los pobres en la Iglesia (The Pact of the Catacombs. The Mission of the poor in the Church). Estella: Editorial Verbo Divino.

Scerri, H. (2015). The Pact of the Catacombs. L'Osservatore Romano (The Roman Observer), 20 November 2015, pp. 6-7. 